\title{
Molecular and Morphological Assessment of Septoria Species Associated with Ornamental Plants in Yunnan Province, China
}

\author{
Yuan-Yan An ${ }^{1}$, Monika C. Dayarathne ${ }^{1}$, Xiang-Yu Zeng ${ }^{1,2}$, Alan J. L. Phillips ${ }^{3}{ }^{\mathbb{D}}$, Kevin D. Hyde ${ }^{2,4}$ \\ and Yong Wang ${ }^{1, *}$
}

Citation: An, Y.-Y.; Dayarathne, M.C.; Zeng, X.-Y.; Phillips, A.J.L.; Hyde, K.D.; Wang, Y. Molecular and Morphological Assessment of Septoria Species Associated with Ornamental Plants in Yunnan Province, China. J. Fungi 2021, 7, 483. https://doi.org/ $10.3390 /$ jof7060483

Academic Editor: Gary A. Strobel

Received: 5 April 2021

Accepted: 5 June 2021

Published: 16 June 2021

Publisher's Note: MDPI stays neutral with regard to jurisdictional claims in published maps and institutional affiliations.

Copyright: (c) 2021 by the authors. Licensee MDPI, Basel, Switzerland. This article is an open access article distributed under the terms and conditions of the Creative Commons Attribution (CC BY) license (https:// creativecommons.org/licenses/by/ $4.0 /)$.
1 Department of Plant Pathology, College of Agriculture, Guizhou University, Guiyang 550025, China; anyuanyan123@sina.com (Y.-Y.A.); monidaya40@gmail.com (M.C.D.); jason.xyzeng@gmail.com (X.-Y.Z.)

2 Center of Excellence in Fungal Research, Mae Fah Luang University, Chiang Rai 57100, Thailand; kdhyde3@gmail.com

3 Faculdade de Ciências, Biosystems and Integrative Sciences Institute (BioISI), Universidade de Lisboa, Campo Grande, 1749-016 Lisbon, Portugal; alan.jl.phillips@gmail.com

4 Institute of Plant Health, Zhongkai, University of Agriculture and Engineering, Haizhu District, Guangzhou 510225, China

* Correspondence: yongwangbis@aliyun.com; Tel.: +86-0187-9889-9302

\begin{abstract}
The Karst landform is the main geographic characteristic in South China. Such areas are rich in vegetation and especially suitable for growth of shrubs and herbaceous plants. In this study, 11 Septoria strains were obtained from different plants' leaves collected in the Kunming Botanical Garden, Yunnan Province, China. Based on single-gene and multi-gene analyses of five gene loci (tef1, rpb2, tub2, ITS, and LSU) and four gene regions (without $L S U$ ), these strains were found to belong to three independent phylogenetic lineages representing five species, including four novel taxa, and one new record for China. Five single gene trees were also provided to evaluate the effectiveness of each gene for discriminating the species, as a result of which $t u b 2$ was found to have the most suitable DNA barcode for rapid identification. Morphological descriptions, illustrations, and comparisons are provided for a more comprehensive assessment. Genealogical Concordance Phylogenetic Species Recognition (GCPSR) with a pairwise homoplasy index (PHI) test was used to evaluate the conclusions of the phylogenetic analyses.
\end{abstract}

Keywords: GCPSR; molecular assessment; new taxa; Septoria

\section{Introduction}

Septoria Sacc., established by Saccardo in 1884, belongs to the Mycosphaerellaceae family of fungi and accommodates around 1000 species [1,2], although only 200 species have been confirmed by molecular data [2]. Many of these species cause leaf spot diseases of numerous cultivated and wild plants [3]. According to its morphology at the primary generic level, Septoria includes coelomycetous asexual morphs, which produce pycnidial conidiomata having holoblastic, hyaline, smooth, filiform-to-cylindrical multi-septate conidia [4-9]. On the basis of a polyphasic approach to taxon delimitation, Verkley et al. [3] pointed out that septoria-like fungi preserved in CBS were in fact distributed over three main clades and introduced a novel genus: Caryophylloseptoria Verkley, Quaedvlieg and Crous. Quaedvlieg et al. [10] re-defined Septoria as having pycnidial to acervular conidiomata and hyaline conidiophores that give rise to conidiogenous cells that proliferate both sympodially and percurrently to form hyaline, filiform conidia with transverse eusepta. Crous et al. [11] introduced Acervuloseptoria on account of its black, erumpent conidiomata, and the old name Septoria capensis G. Winter was transferred to this genus [12]. More DNA sequence data are necessary to support the morphological characters in this species identification [10].

In this study, 11 Septoria strains were obtained from different ornamental plants in a South China Karst region. Morphological comparisons, phylogenetic analyses based 
on five gene loci, DNA base-pair differences, and GCPSR evaluation confirmed that they formed three phylogenetic lineages representing five Septoria species comprising four novel species and one new Chinese record.

\section{Materials and Methods}

\subsection{Fungus Collection and Isolation}

The isolates included in this study were collected from the Kunming Botanical Garden, Yunnan Province, China, in 2018. Pure cultures were obtained by single-spore isolations following the methods of surface sterilization and incubation of specimens [13]. After $24 \mathrm{~h}$ of incubation, germinated conidia were transferred to the new potato-dextrose agar (PDA) medium and incubated at $25^{\circ} \mathrm{C}$. The holotype specimens were deposited in the Herbarium of the Department of Plant Pathology, Agricultural College, Guizhou University (HGUP). The type cultures were deposited in the Culture Collection at the Department of Plant Pathology, Agriculture College, Guizhou University, China (GUCC), and the Mae Fah Luang University Culture Collection (MFLUCC) in Thailand (Table 1).

Table 1. Strains numbers and GenBank accession numbers for phylogenetic study.

\begin{tabular}{|c|c|c|c|c|c|c|}
\hline \multirow{2}{*}{ Species } & \multirow{2}{*}{ Isolate No. } & \multicolumn{5}{|c|}{ GenBank Accession No. } \\
\hline & & tef1 & tub2 & $r p b 2$ & LSU & ITS \\
\hline Cercospora beticola & CBS 124.31 & KF253246 & KF252780 & KF252304 & KF251802 & KF251298 \\
\hline Septoria aegopodina & CBS 123741 & KF253282 & KF252807 & - & KF251838 & KF251334 \\
\hline S. anthrisci & CBS 109020 & KF253286 & KF252811 & KF252340 & KF251843 & KF251339 \\
\hline S. anthurii & CBS 346.58 & KF253288 & KF252813 & KF252342 & KF251845 & KF251341 \\
\hline S. apiicola & CBS 400.54 & KF253292 & KF252817 & KF252346 & KF251849 & KF251345 \\
\hline S. astericola & CBS 128593 & KF253294 & KF252819 & KF252348 & KF251851 & KF251347 \\
\hline S. astragali & CBS 109116 & KF253298 & KF252823 & KF252352 & KF251855 & KF251351 \\
\hline S. atropurpurea & CBS 348.58 & KF253299 & KF252824 & KF252353 & KF251856 & KF251352 \\
\hline S. bothriospermi & CBS 128599 & KF253301 & KF252826 & KF252355 & KF251858 & KF251354 \\
\hline S. bupleuricola & CBS 128603 & KF253303 & KF252828 & KF252357 & KF251860 & KF251356 \\
\hline S. calendulae & CBS 349.58 & KF253304 & KF252829 & KF252358 & KF251861 & KF251357 \\
\hline S. callistephi & CBS 128590 & KF253305 & KF252830 & KF252359 & KF251862 & KF251358 \\
\hline S. campanulae & CBS 128604 & KF253308 & KF252833 & KF252362 & KF251865 & KF251361 \\
\hline S. carvi & KML 1833 & - & - & - & - & KX453687 \\
\hline S. cerastii & CBS 128612 & KF253311 & KF252836 & KF252365 & KF251868 & KF251364 \\
\hline S. cf. agrimoniicola & CBS 128602 & KF253284 & KF252809 & KF252338 & KF251841 & KF251337 \\
\hline S. cf. rubi & CBS 128646 & KF253314 & KF252839 & KF252368 & KF251871 & KF251367 \\
\hline S. cf. sonchi & CBS 128757 & KF253500 & KF253020 & KF252546 & KF252057 & KF251552 \\
\hline S. cf. stachydicola & CBS 128662 & KF253513 & KF253034 & KF252559 & KF252071 & KF251566 \\
\hline S. chamaecisti & CBS 350.58 & KF253318 & KF252843 & KF252372 & KF251875 & KF251371 \\
\hline S. chelidonii & CBS 128607 & KF253319 & KF252844 & KF252373 & KF251876 & KF251372 \\
\hline S. chromolaenae & CBS $113373^{\mathrm{T}}$ & KF253321 & KF252846 & KF252375 & KF251878 & KF251374 \\
\hline S. chrysanthemella & CBS 128716 & KF253325 & KF252850 & KF252379 & KF251882 & KF251378 \\
\hline S. cirsii & CBS 128621 & KF253328 & KF252853 & KF252382 & KF251885 & KF251381 \\
\hline S. citri & CBS 315.37 & KF253465 & - & KF252511 & KF252021 & KF251516 \\
\hline S. citricola & CBS $356.36^{\mathrm{T}}$ & KF253329 & KF252854 & KF252383 & KF251886 & KF251382 \\
\hline S. clematidis & CBS 108983 & KF253330 & KF252855 & KF252384 & KF251887 & KF251383 \\
\hline
\end{tabular}


Table 1. Cont.

\begin{tabular}{|c|c|c|c|c|c|c|}
\hline \multirow{2}{*}{ Species } & \multirow{2}{*}{ Isolate No. } & \multicolumn{5}{|c|}{ GenBank Accession No. } \\
\hline & & tef1 & tub2 & $r p b 2$ & LSU & ITS \\
\hline S. codonopsidis & CBS 128620 & KF253333 & KF252858 & KF252387 & KF251890 & KF251386 \\
\hline S. convolvuli & CBS 128627 & KF253336 & KF252861 & KF252390 & KF251893 & KF251389 \\
\hline S. coprosmae & CBS 113391 & KF253255 & KF252787 & KF252313 & KF251812 & KF251308 \\
\hline S. crepidis & CBS 128619 & KF253338 & KF252863 & KF252392 & KF251895 & KF251391 \\
\hline S. cretae & CBS $135095^{\mathrm{T}}$ & - & KF252720 & - & KF251736 & KF251233 \\
\hline S. cruciatae & CBS 123747 & KF253340 & KF252865 & KF252394 & KF251897 & KF251393 \\
\hline S. cucubali & CBS 102386 & KF253344 & KF252869 & KF252398 & KF251901 & KF251397 \\
\hline S. cucurbitacearum & CBS 178.77 & KF253346 & - & KF252400 & KF251903 & KF251399 \\
\hline S. dearnessii & CBS 128624 & KF253347 & KF252871 & KF252401 & KF251904 & KF251400 \\
\hline S. digitalis & CBS 391.63 & KF253349 & KF252873 & KF252403 & KF251906 & KF251402 \\
\hline S. dispori & GUCC $2127.1^{\mathrm{T}}$ & MT996515 & MT984348 & MT993632 & MT985366 & MT974584 \\
\hline S. dispori & GUCC 2164.3 & MT996523 & MT984357 & MT993641 & MT985375 & MT974593 \\
\hline S. dispori & GUCC 2164.4 & MT996524 & MT984358 & MT993642 & MT985376 & MT974594 \\
\hline S. dispori & GUCC 2127.4 & MT996517 & MT984350 & MT993634 & MT985368 & MT974586 \\
\hline S. dolichospora & CBS 129152 & KF253350 & KF252874 & - & KF251907 & KF251403 \\
\hline S. dysentericae & CBS 131892 & KF253353 & KF252877 & KF252406 & KF251910 & KF251406 \\
\hline S. ekmaniana & CBS 113612 & KF253355 & KF252879 & - & KF251912 & KF251408 \\
\hline S. epambrosiae & CBS 128629 & KF253356 & KF252880 & KF252407 & KF251913 & KF251409 \\
\hline S. epilobii & CBS $109084^{\mathrm{T}}$ & KF253358 & KF252882 & KF252409 & KF251915 & KF251411 \\
\hline S. erigerontis & CBS 109094 & KF253360 & KF252884 & KF252411 & KF251917 & KF251413 \\
\hline S. eucalyptorum & CBS $118505^{\mathrm{T}}$ & KF253365 & KF252889 & KF252415 & KF251921 & KF251417 \\
\hline S. exotica & CBS 163.78 & KF253366 & KF252890 & KF252416 & KF251922 & KF251418 \\
\hline S. galeopsidis & CBS $102411^{\mathrm{T}}$ & KF253372 & KF252896 & KF252422 & KF251928 & KF251424 \\
\hline S. gentianae & CBS 128633 & KF253374 & KF252898 & KF252424 & KF251930 & KF251426 \\
\hline S. gerberae & CBS 410.61 & KF253468 & KF252988 & KF252514 & KF252024 & KF251519 \\
\hline S. glycines & CBS 336.53 & KF253377 & KF252901 & - & KF251933 & KF251429 \\
\hline S. glycinicola & CBS $128618^{\mathrm{T}}$ & KF253378 & KF252902 & KF252427 & KF251934 & KF251430 \\
\hline S. hederae & CBS 566.88 & KF253470 & KF252990 & KF252515 & KF252026 & KF251521 \\
\hline S. helianthi & CBS 123.81 & KF253379 & KF252903 & KF252428 & KF251935 & KF251431 \\
\hline S. helianthicola & CBS 122.81 & KF253380 & KF252904 & KF252429 & KF251936 & KF251432 \\
\hline S. hibiscicola & CBS 128615 & KF253382 & KF252906 & KF252431 & KF251938 & KF251434 \\
\hline S. hippocastani & СРС 23103 & KF253510 & KF253031 & KF252556 & KF252068 & KF251563 \\
\hline S. justiciae & CBS 128625 & KF253385 & KF252909 & KF252434 & KF251941 & KF251437 \\
\hline S. lactucae & CBS 108943 & KF253387 & KF252911 & KF252436 & KF251943 & KF251439 \\
\hline S. lamiicola & CBS 123884 & KF253397 & KF252921 & KF252446 & KF251953 & KF251449 \\
\hline S. lepidiicola & CBS 128635 & KF253398 & KF252922 & KF252447 & KF251954 & KF251450 \\
\hline S. leptostachyae & CBS 128613 & KF253399 & KF252923 & KF252448 & KF251955 & KF251451 \\
\hline S. leucanthemi & CBS 109090 & KF253403 & KF252927 & KF252452 & KF251959 & KF251455 \\
\hline S. limonum & CBS 419.51 & KF253407 & KF252931 & KF252456 & KF251963 & KF251459 \\
\hline S. linicola & CBS 316.37 & KF253408 & KF252932 & KF252457 & KF251964 & KF251460 \\
\hline
\end{tabular}


Table 1. Cont.

\begin{tabular}{|c|c|c|c|c|c|c|}
\hline \multirow{2}{*}{ Species } & \multirow{2}{*}{ Isolate No. } & \multicolumn{5}{|c|}{ GenBank Accession No. } \\
\hline & & tef1 & tub2 & $r p b 2$ & LSU & ITS \\
\hline S. lobeliae & CBS 113392 & KF253460 & KF252981 & KF252507 & KF252016 & KF251511 \\
\hline S. longipes & GUCC $2131.1^{\mathrm{T}}$ & - & MT984351 & MT993635 & MT985369 & MT974587 \\
\hline S. lycoctoni & CBS 109089 & KF253409 & KF252933 & KF252458 & KF251965 & KF251461 \\
\hline S. lycopersici & CBS 128654 & KF253410 & KF252934 & KF252459 & KF251966 & KF251462 \\
\hline S. lycopicola & CBS 128651 & KF253412 & KF252936 & KF252461 & KF251968 & KF251464 \\
\hline S. lysimachiae & CBS 102315 & KF253413 & KF252937 & KF252462 & KF251969 & KF251465 \\
\hline S. malagutii & CBS $106.80^{\mathrm{T}}$ & KF253418 & - & KF252467 & KF251974 & KF251470 \\
\hline S. matricariae & CBS 109001 & KF253420 & KF252943 & KF252469 & KF251976 & KF251472 \\
\hline S. mazi & CBS 128755 & KF253422 & KF252945 & KF252471 & KF251978 & KF251474 \\
\hline S. melissae & CBS 109097 & KF253423 & KF252946 & KF252472 & KF251979 & KF251475 \\
\hline S. menthae & CBS 404.34 & KF253424 & KF252947 & - & KF251980 & KF251476 \\
\hline S. napelli & CBS 109105 & KF253426 & KF252949 & KF252474 & KF251982 & KF251478 \\
\hline S. obesa & CBS 128623 & KF253429 & KF252952 & KF252477 & KF251985 & KF251481 \\
\hline S. oenanthicola & CBS $128649^{\mathrm{T}}$ & KF253433 & KF252954 & KF252239 & KF251737 & KF251234 \\
\hline S. oenanthis & CBS 128667 & KF253432 & KF252953 & - & KF251989 & KF251485 \\
\hline S. orchidearum & CBS $128631^{\mathrm{T}}$ & KF253434 & KF252955 & KF252482 & KF251990 & KF251486 \\
\hline S. pachyspora & CBS 128652 & KF253437 & KF252958 & KF252485 & KF251993 & KF251488 \\
\hline S. paridis & CBS 109111 & KF253438 & KF252959 & KF252486 & KF251994 & KF251489 \\
\hline S. passifloricola & CBS 102701 & KF253442 & KF252963 & KF252490 & KF251998 & KF251493 \\
\hline S. perillae & CBS 128655 & KF253444 & KF252965 & KF252491 & KF252000 & KF251495 \\
\hline S. petroselini & CBS 182.44 & KF253446 & KF252967 & KF252493 & KF252002 & KF251497 \\
\hline S. phlogis & CBS 128663 & KF253448 & KF252969 & KF252495 & KF252004 & KF251499 \\
\hline S. pileicola & GUCC 2131.3 & MT996519 & MT984353 & MT993637 & MT985371 & MT974589 \\
\hline S. pileicola & GUCC $2131.4^{\mathrm{T}}$ & MT996520 & МT984354 & MT993638 & MT985372 & МТ974590 \\
\hline S. polygonorum & CBS 109834 & KF253453 & KF252974 & KF252500 & KF252009 & KF251504 \\
\hline S. posoniensis & CBS 128645 & KF253456 & KF252977 & KF252503 & KF252012 & KF251507 \\
\hline S. protearum & CBS $778.97^{\mathrm{T}}$ & KF253472 & KF252992 & KF252517 & KF252028 & KF251523 \\
\hline S. protearum & GUCC 2127.3 & MT996516 & MT984349 & MT993633 & MT985367 & MT974585 \\
\hline S. pseudonapelli & CBS $128664^{\mathrm{T}}$ & KF253475 & KF252995 & KF252520 & KF252031 & KF251526 \\
\hline S. putrida & CBS 109088 & KF253477 & KF252997 & KF252522 & KF252033 & KF251528 \\
\hline S. rumicum & CBS 503.76 & KF253478 & KF252998 & KF252523 & KF252034 & KF251529 \\
\hline S. saccardoi & CBS 128756 & KF253479 & KF252999 & KF252524 & KF252035 & KF251530 \\
\hline S. sanguisorbigena & GUCC 2131.2 & MT996518 & MT984352 & MT993636 & MT985370 & MT974588 \\
\hline S. sanguisorbigena & GUCC 2164.1 & MT996521 & MT984355 & MT993639 & MT985373 & MT974591 \\
\hline S. sanguisorbigena & GUCC $2164.2^{\mathrm{T}}$ & MT996522 & MT984356 & MT993640 & MT985374 & MT974592 \\
\hline S. scabiosicola & CBS 109093 & KF253487 & KF253007 & KF252532 & KF252043 & KF251538 \\
\hline S. senecionis & CBS $102366^{\mathrm{T}}$ & KF253492 & KF253012 & KF252538 & KF252049 & KF251544 \\
\hline S. siegesbeckiae & CBS 128659 & KF253494 & KF253014 & KF252540 & KF252051 & KF251546 \\
\hline S. sii & CBS 102370 & KF253497 & KF253017 & KF252543 & KF252054 & KF251549 \\
\hline S. sisyrinchii & CBS 112096 & KF253499 & KF253019 & KF252545 & KF252056 & KF251551 \\
\hline
\end{tabular}


Table 1. Cont.

\begin{tabular}{ccccccc}
\hline \multirow{2}{*}{ Species } & \multirow{2}{*}{ Isolate No. } & \multicolumn{4}{c}{ GenBank Accession No. } \\
\cline { 3 - 7 } & & tef1 & tub2 & rpb2 & LSU & ITS \\
\hline S. stachydicola & CBS 128668 & KF253512 & KF253033 & KF252558 & KF252070 & KF251565 \\
\hline S. stachydis & CBS 109127 & KF253517 & KF253038 & KF252563 & KF252075 & KF251570 \\
\hline S. stellariae & CBS 102376 & KF253521 & KF253042 & KF252567 & KF252079 & KF251574 \\
\hline S. taraxaci & CBS 567.75 & KF253524 & KF253045 & KF252570 & KF252082 & KF251577 \\
\hline S. tinctoriae & CBS 129154 & KF253525 & KF253046 & KF252571 & KF252083 & KF251578 \\
\hline S. tormentillae & CBS 128647 & KF253527 & KF253048 & KF252573 & KF252085 & KF251580 \\
\hline S. urticae & CBS 102375 & KF253530 & KF253051 & KF252576 & KF252088 & KF251583 \\
\hline S. verbascicola & CBS 102401 & KF253531 & KF253052 & KF252577 & KF252089 & KF251584 \\
\hline S. verbenae & CBS 113438 & KF253532 & KF253053 & KF252578 & KF252090 & KF251585 \\
\hline S. villarsiae & CBS 514.78 & KF253534 & KF253055 & KF252580 & KF252092 & KF251587 \\
\hline S. violae-palustris & CBS 128644 & KF253537 & KF253058 & KF252583 & KF252095 & KF251590 \\
\hline
\end{tabular}

Ex-type isolates are labeled with "T".

\subsection{Morphological Studies}

Morphological characters were recorded from cultures that had been incubated for 2 to 3 weeks. For light microscopy, the relevant structures were mounted in Shear's liquid, distilled water or lactic acid and examined with an Olympus BX53 microscope. Measurements of 30 conidia and other structures were made at a magnification of $1000 \times$ [14]. Taxonomic information of the new taxa was submitted to the MycoBank database (www.mycobank.org, accessed on 24 March 2021).

\subsection{DNA Extraction, Amplification (PCR), and Sequencing}

Methods outlined in [15] were followed for DNA extraction, amplification (PCR), sequencing, and phylogenetic analysis. Fresh fungal mycelia of strains were harvested using a sterile scalpel, and the genomic DNA was isolated using A BIOMIGA Fungus Genomic DNA Extraction Kit (GD2416) according to the manufacturer's protocol. The DNA was amplified in a $25 \mu \mathrm{L}$ reaction volume containing $2.5 \mu \mathrm{L} 10 \times$ PCR buffer, $1 \mu \mathrm{L}$ of each primer $(10 \mu \mathrm{M}), 1 \mu \mathrm{L}$ template DNA, $0.25 \mu \mathrm{L}$ Taq DNA polymerase (Promega, Madison, WI,

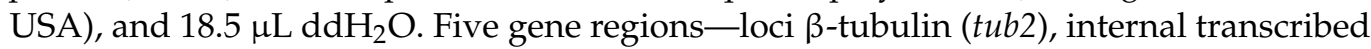
spacer (ITS), Translation elongation factor 1-alpha (tef1), $28 \mathrm{~S}$ nrDNA (LSU), and RNA polymerase II second largest subunit ( $r p b 2)$-were targeted for Polymerase Chain Reaction (PCR) amplification and subsequent sequencing. The primers used and amplification conditions of the genes are listed in Table 2. The DNA sequences were submitted to GenBank and their accession numbers are provided in Table 1. The generated sequences for each locus and the reference sequences of ex-type or representative sequences of Septoria species downloaded from GenBank (Table 1) were aligned with the online version of MAFFT v. $7.307[16,17]$. 
Table 2. Primers, primer sequences, and thermal cycling program for PCR amplification.

\begin{tabular}{|c|c|c|c|c|c|}
\hline Locus & Primer & Primer Sequence $5^{\prime}$ to $3^{\prime}$ & $\begin{array}{c}\text { Annealing } \\
\text { Temperature }\left({ }^{\circ} \mathrm{C}\right)\end{array}$ & Direction & Reference \\
\hline \multirow[t]{2}{*}{ tef1 } & EF1-728F & CATCGAGAAGTTCGAGAAGG & \multirow{2}{*}{52} & Forward & [18] \\
\hline & $\mathrm{EF}-2$ & GGARGTACCAGTSATCATGTT & & Reverse & {$[19]$} \\
\hline \multirow[t]{2}{*}{ tub2 } & $\mathrm{T} 1$ & AACATGCGTGAGATTGTAAGT & \multirow{2}{*}{52} & Forward & [20] \\
\hline & $\beta$-Sandy-R & GCRCGNGGVACRTACTTGTT & & Reverse & [21] \\
\hline \multirow[t]{2}{*}{$r p b 2$} & fRPB2-5F & GAYGAYMGWGATCAYTTYGG & \multirow{2}{*}{49} & Forward & {$[22]$} \\
\hline & fRPB2-414R & ACMANNCCCCARTGNGWRTTRTG & & Reverse & [23] \\
\hline \multirow[t]{2}{*}{ LSU } & LSU1Fd & GRATCAGGTAGGRATACCCG & \multirow{2}{*}{52} & Forward & [24] \\
\hline & LR5 & TCCTGAGGGAAACTTCG & & Reverse & [25] \\
\hline \multirow[t]{2}{*}{ ITS } & ITS5 & GGAAGTAAAAGTCGTAACAAGG & \multirow{2}{*}{52} & Forward & [26] \\
\hline & ITS4 & TCCTCCGCTTATTGATATGC & & Reverse & {$[26]$} \\
\hline
\end{tabular}

\subsection{Phylogenetic Analyses}

The alignments were checked and manually improved where necessary using MEGA v. 5 [27]. Phylogenetic analyses were performed by maximum parsimony (MP), maximum likelihood (ML), and Bayesian methods for individual and combined locus datasets. Ambiguous regions were excluded from the analyses and gaps were treated as missing data. Maximum parsimony analysis was performed in PAUP v. 4.0b10 [28] using the heuristic search option with 100 random taxon additions and tree bisection and re-connection (TBR) as the branch-swapping algorithm with Maxtrees $=5000$. Branches of zero length were collapsed and all multiple, and equally most parsimonious trees were saved. The robustness of the trees obtained was evaluated by 1000 bootstrap replications [29]. Other measures calculated included tree length (TL), consistency index (CI), retention index (RI), and rescaled consistency index (RC).

The resulting PHYLIP file was used to generate the ML tree on the CIPRES Science Gateway [30] using RAxML-HPC2 black box with 1000 bootstrap replicates and GTRGAMMA as the nucleotide substitution model. Bayesian analyses were launched with random starting trees for 10,000,000 generations. The heat parameter was set at 0.15 and trees were saved every 1000 generations until the average standard deviation of split frequencies reached 0.01 (stop value). Burn-in was set to $25 \%$ after which the likelihood values were considered to be stationary. All resulting trees were visualized with FigTree v. 1.4.3 (Institute of Evolutionary Biology, University of Edinburgh, UK) [31].

\subsection{Genealogical Concordance Phylogenetic Species Recognition Analysis}

The Genealogical Concordance Phylogenetic Species Recognition (GCPSR) concept with a pairwise homoplasy index (PHI) test was used to analyze the new species, their species boundaries, and their most closely related taxa as described by Quaedvlieg et al. [32]. The recombination level within phylogenetically closely related species was determined with the PHI test performed using SplitsTree4 [33,34]. The concatenated datasets (tef1, rpb2, $t u b 2$, ITS, and $L S U$ ) were used. The relationships between different taxa were visualized in splits graphs with both the Log-Det transformation and splits decomposition options. A pairwise homoplasy index below a 0.05 threshold $(\mathrm{Fw}<0.05)$ indicated the presence of significant recombination in the dataset.

\section{Results}

\subsection{Phylogenetic Analyses}

Eleven Septoria strains isolated from different plant hosts were sequenced. PCR products of 450-536 bp (tef1), 440-453 bp (tub2), 458-524 bp (ITS), 799-863 bp (LSU), and 718-1083 bp (rpb2) were obtained. By alignment with the single-gene region and 
then in combination in the order of tef1, rpb2, tub2, ITS, and LSU with Cercospora beticola (CBS 124.31), 2434 characters were obtained: tef1, 1-479; rpb2, 480-824; tub2, 825-1149; ITS, 1159-163; and LSU, 1636-2434. Among these characters, 1672 were constant, while 195 variable characters were parsimony-uninformative and 567 were parsimony informative. The parameters of the MP phylogenetic trees are shown in Table 3, and the procedure yielded a single most parsimonious tree (Figure 1). Similar topologies were obtained by MP, ML, and Bayesian methods. In the Septoria phylogenetic tree (Figure 1), all Septoria isolates were grouped together, but only the $\mathrm{BI}$ support was high $(\mathrm{BPP}=1)$, while the three major clades received greater statistical support (Branch 1: $\mathrm{ML} / \mathrm{BI}=98 \% / 0.99$; Branches 2: $\mathrm{MP} / \mathrm{ML} / \mathrm{BI}=88 \% / 87 \% / 0.99$; Branch 3: $\mathrm{MP} / \mathrm{ML} / \mathrm{BI}=88 \% / 80 \% / 1.00$ ). Six strains (GUCC 2131.1, GUCC 2131.2, GUCC 2131.3, GUCC 2131.4, GUCC 2164.1, and GUCC 2164.2) were grouped in the clade that included S. posoniensis and S. exotica (MP: 95\%, ML: 92\% and BPP: 0.94) in Branch 1. In this group, five strains (GUCC 2131.2, GUCC 2131.3, GUCC 2131.4, GUCC 2164.1 and GUCC 2164.2) formed an independent branch adjacent to GUCC 2131.1 and S. posoniensis (MP: 76\%, ML: 86\%, and BPP: 0.95), but these five strains were split into two sub-branches: one containing GUCC 2131.2, GUCC2164.1, and GUCC2164.2, and the other containing GUCC 2131.3 and GUCC2131.4, with good support (MP: 75\%; BPP: 1.00). Strain GUCC 2127.3 was aligned to the branch that included S. chamaecisti, S. citri, S. citricola, S. protearum, and S. limonum with high statistical support (MP: 98\%, ML: 100\% and BPP: 1) but small phylogenetic distances. Strains GUCC 2164.3, GUCC 2164.4, GUCC 2127.1, and GUCC 2127.4 formed a strongly supported group (MP: 95\%; ML: 100\%; BPP: 1.00) closely related to $S$. coprosmae and S. verbenae with good support values (MP: 85\%; BPP: 0.96). In Branch 2, four strains clustered in a clade in which GUCC 2127.1, GUCC2164.3 and GUCC2164.4 formed a sub-group, were very close to GUCC 2127.4, supported by high statistical values (MP: 95\%, ML: 100\%, and BPP: 1 ).

Table 3. Parameters for MP analyses.

\begin{tabular}{cccccccc}
\hline & Total Characters & $\begin{array}{c}\text { Number of Parsimony-Informative } \\
\text { Characters }\end{array}$ & TL & CI & RI & HI & RC \\
\hline ITS & 486 & 43 & 176 & 0.642 & 0.76 & 0.358 & 0.488 \\
\hline LSU & 799 & 31 & 112 & 0.625 & 0.863 & 0.375 & 0.539 \\
\hline$r p b 2$ & 345 & 18 & 780 & 0.273 & 0.746 & 0.727 & 0.204 \\
\hline$t e f 1$ & 469 & 231 & 1498 & 0.379 & 0.707 & 0.621 & 0.268 \\
\hline$t u b 2$ & 325 & 165 & 1221 & 0.326 & 0.774 & 0.674 & 0.252 \\
\hline$t e f 1+r p b 2+t u b 2+$ ITS & 1625 & 548 & 3927 & 0.328 & 0.716 & 0.672 & 0.235 \\
\hline$t p p b 2+t u b 2+$ ITS + LSU & 2434 & 567 & 4075 & 0.330 & 0.720 & 0.670 & 0.238 \\
\hline
\end{tabular}

We also compared the DNA base-pair differences in five different loci between our strains and related species (Supplementary Table S1). This revealed that the LSU gene region was too conserved for species-level identification, and the ITS had little value, but tef1, tub2, and $r p b 2$ provided more than $80 \%$ of the DNA base-pair differences (Supplementary Table S1). We also built a phylogenetic tree based on four loci, excluding the LSU region (Figure 2), using the parameters for MP analysis in Table 3. The topology showed highly similar placements of our strains in the Septoria in Figure 1; however, in Figure 2 only two branches were formed and all members of Branch 3 were integrated with Branch 1. To evaluate the distinctive effectiveness of different DNA markers, five single gene trees were constructed (Supplementary Figures S1-S5) and all MP parameters were as indicated in Table 3. Through comparison, we found that only tub2 and tef 1 included more parsimonious characters $(50.7 \%$ and $49.2 \%)$, and the sequence of $t u b 2$ was shorter than that of tef1. Moreover, the topology originating from the $t u b 2$ gene region was more similar to Figure 2. 


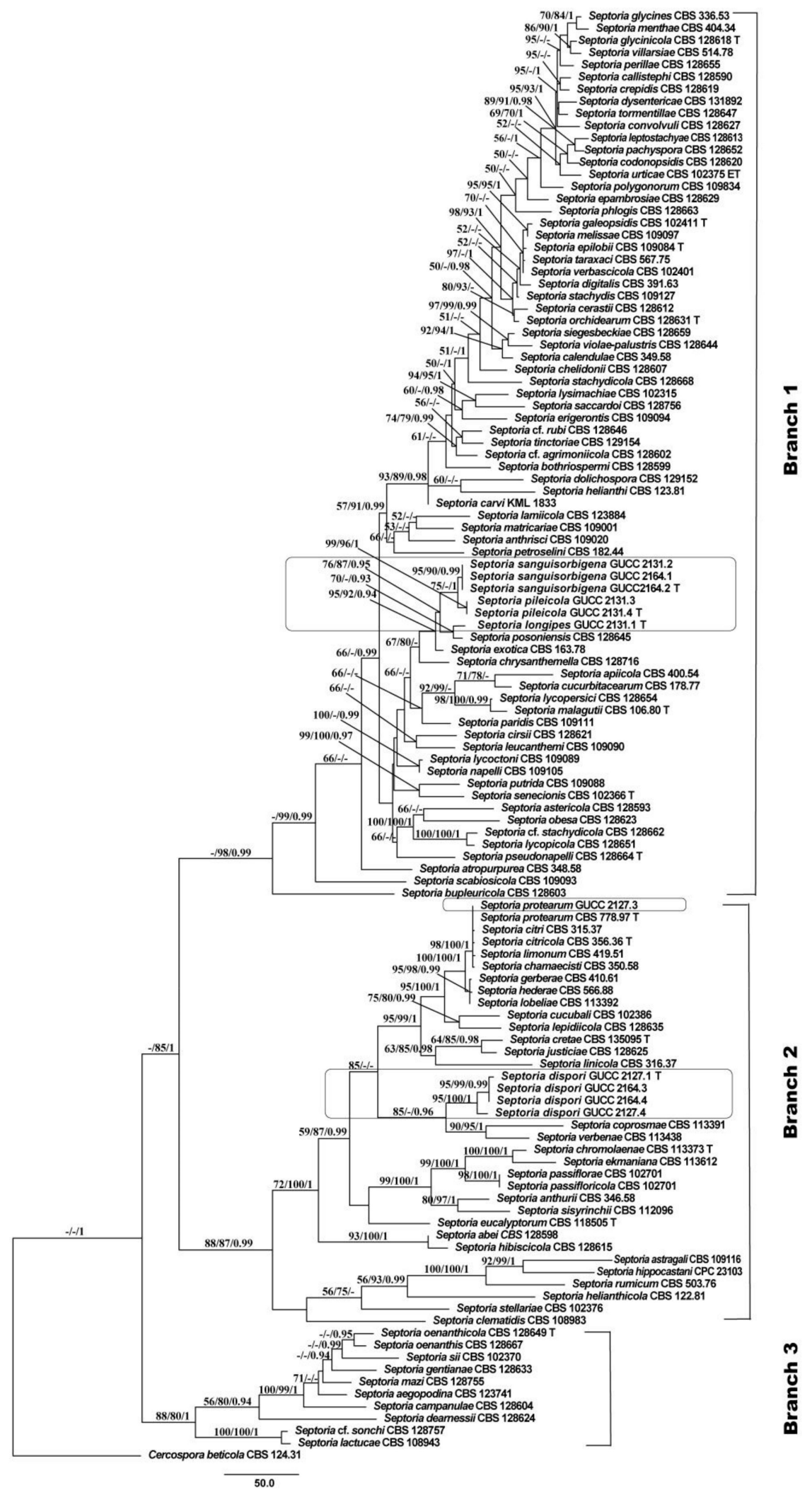

Figure 1. Maximum Parsimony (MP) topology of Septoria generated from a combination of tef1, rpb2, tub2, ITS, and LSU sequences. Cercospora beticola (CBS 124.31) was used as outgroup taxon. MP and ML above 50\% and BPP above 0.90 were placed close to topological nodes and separated by "/", otherwise were labeled with "-". 


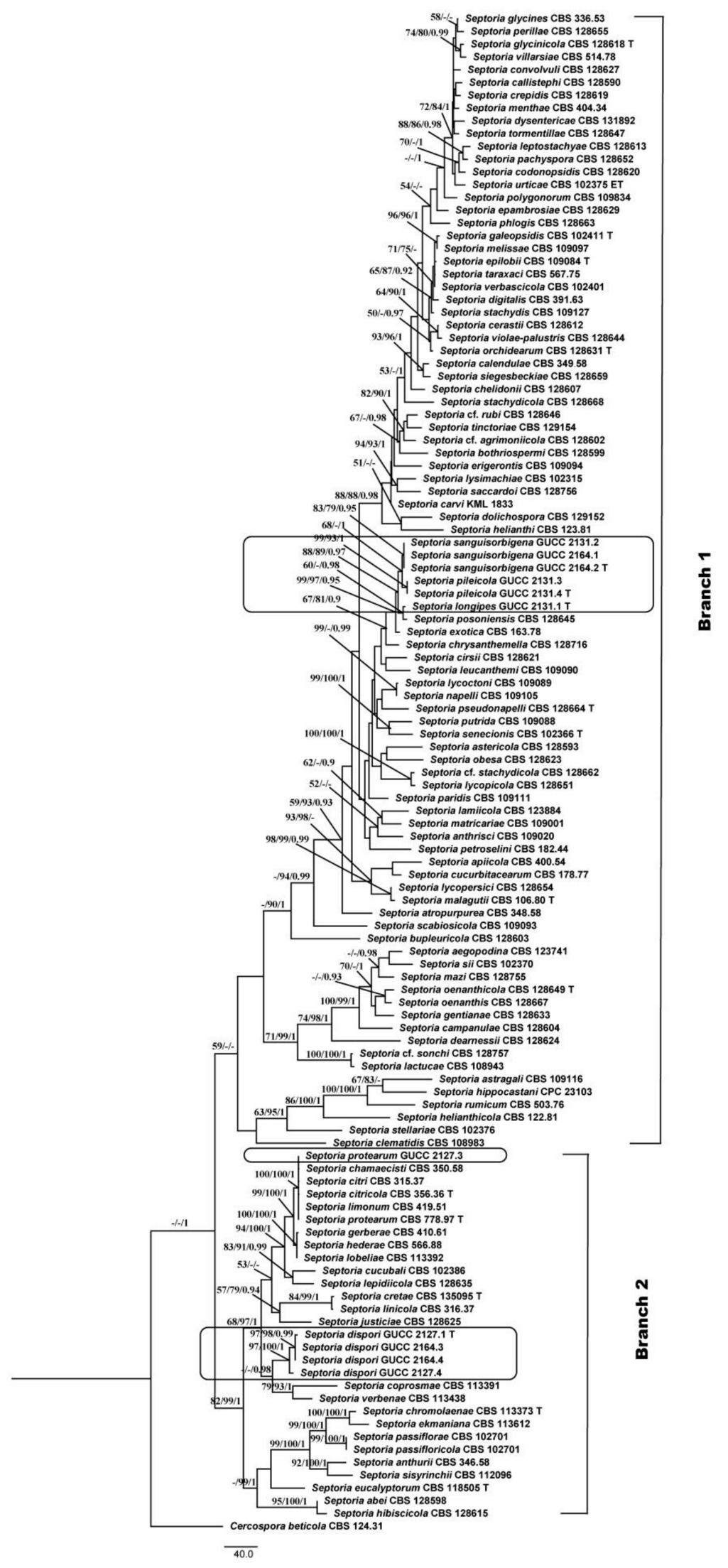

Figure 2. Maximum parsimony (MP) topology of Septoria generated from a combination of tef1, rpb2, tub2, and ITS sequences. Cercospora beticola (CBS 124.31) was used as an outgroup taxon. MP and ML above 50\% and BPP above 0.90 were placed close to topological nodes and separated by "/"; otherwise, they were labeled with "-". 


\subsection{Genealogical Concordance Phylogenetic Species Recognition}

In order to determine evolutionary independence, the GCPSR concept was applied to the GUCC 2164.2, GUCC 2131.4, GUCC 2131.1, and related taxa S. chrysanthemella (CBS 128716), S. exotica (CBS 163.78), and S. posoniensis (CBS 128645). A pairwise homoplasy index ( $\mathrm{PHI}$ or $\mathrm{Fw}$ ) less than 0.05 provided evidence of the presence of significant recombination within a dataset. According to the GCPSR analysis, our dataset showed PHI of 0.116, indicating no significant genetic recombination among our strains and related taxa. Hence, it was concluded that these taxa were significantly different from each other.

For GUCC 2164.3 and GUCC 2127.4 and related species S. coprosmae (CBS 113391) and S. verbenae (CBS 113438), the pairwise homoplasy index ( $\mathrm{PHI}$ or $\mathrm{Fw}$ ) was $1.173 \times 10^{-8}$, which provided evidence for the presence of significant recombination within a dataset. The four strains could belong to a single species.

\subsection{Taxonomy}

(1) Septoria sanguisorbigena Y.Y. An \& Yong Wang bis, sp. nov. (Figure 3)

MycoBank MB 839125
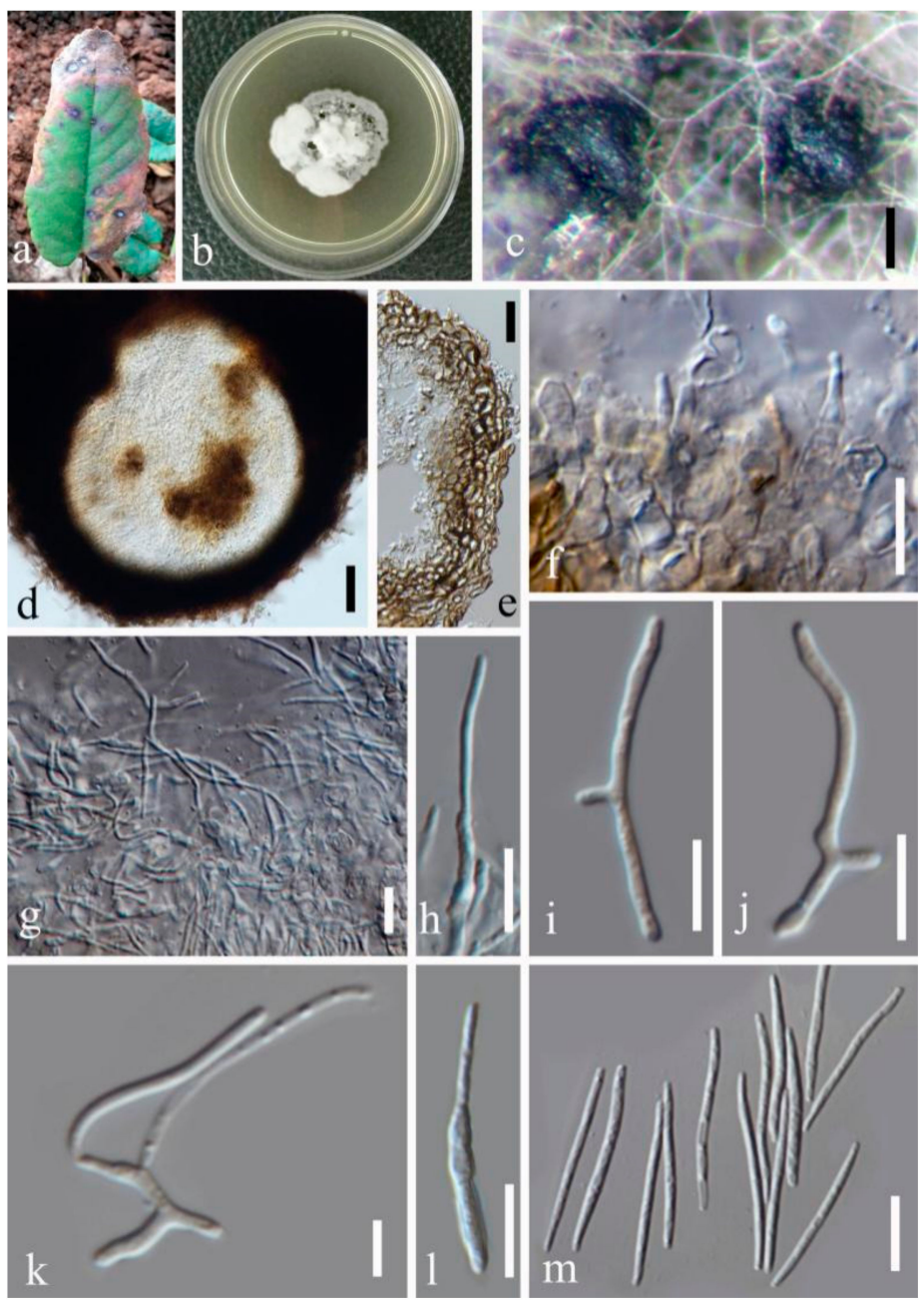

Figure 3. Septoria sanguisorbigena (GUCC 2164.2) (a) Leaf spot symptoms on the host. (b) Colony on PDA culture. (c) Conidiomata formed on PDA culture. (d) Section through a conidioma. (e) Peridium. (f-k) Conidiogenous cells, $(\mathbf{1}, \mathbf{m})$ Conidia. Scale bars: (c) $=25 \mu \mathrm{m},(\mathbf{d})=50 \mu \mathrm{m}$, $(\mathbf{e})=20 \mu \mathrm{m},(\mathbf{f}-\mathbf{j})=10 \mu \mathrm{m},(\mathbf{k})=5 \mu \mathrm{m},(\mathbf{l}, \mathbf{m})=10 \mu \mathrm{m}$.

Etymology: The name refers to the plant host, from which the fungus was collected. 
Description in vitro: Colonies: on PDA 15-25 mm diameter after 2 weeks with a undulating even margin, restricted, irregularly pustulate; the surface almost black with low and finely felted diffuse, grey-to-white aerial mycelium. Conidiomata: pycnidial, epiphyllous, immersed, subglobose to globose, black, 120-250 $\mu \mathrm{m}$ diameter; ostiolum central, circular, initially 25-35 $\mu \mathrm{m}$ wide, later becoming more irregular and up to $100 \mu \mathrm{m}$ wide, conidiomatal wall 20-40 $\mu \mathrm{m}$ thick, composed of an outer layer of angular-to-irregular cells mostly $4.5-10 \mu \mathrm{m}$ diameter with pale to orange-brown walls and an inner layer of isodiametric, hyaline cells 7-20 $\mu \mathrm{m}$ diamater. Conidiogenous cells: hyaline, discrete, holoblastic, sympodially or percurrently proliferating, ampulliform, 4.5-8 $\times 1.5-2.5 \mu \mathrm{m}$ (avg. $=5.6 \times 2 \mu \mathrm{m}, n=30)$. Conidia: hyaline, filiform, straight to somewhat flexuous, the upper cell tapered into obtuse apex, relatively wide truncated base, (1-)3-5(-7) septate, not or only indistinctly constricted at the septa, contents granular or with minute oil-droplets around the septa and at the ends, $12.5-30 \times 0.6-2 \mu \mathrm{m}($ avg. $=20.5 \times 1.3 \mu \mathrm{m}, n=30)$. Sexual morph unknown.

Type: CHINA, Yunnan Province, Kunming Botanical Garden, from leaves of Sanguisorba officinalis L., February 2018, Y.Y. An (HGUP 2164.2, holotype); ex-type culture GUCC 2164.2; isotype culture MFLUCC 20-0185.

Other material examined: CHINA, Yunnan Province, Kunming Botanical Garden, from leaves of Sanguisorba officinalis, February 2018, Y.Y. An (HGUP 2164.2); from leaves of Pilea cadierei Gagnep. \& Guillaumin, February 2018, Y.Y. An (HGUP 2131.2).

Notes: Phylogenetic analyses confirmed that three strains (GUCC 2131.2, GUCC 2164.1, and GUCC 2164.2) had a close relationship with S. chrysanthemella, S. exotica, S. longipes, $S$. pileicola, and $S$. posoniensis and this was supported by credible statistic values of the MP and ML methods (Figure 1). However, the independent branch only included those strains with high support values (MP: 95\%, ML: 90\%, and BPP: 0.99) adjacent to S. pileicola with moderate MP bootstrap but 1.00 BPP support. The new species had narrower conidia $(0.6-2 \mu \mathrm{m})$ with $3-5$ septa than those of $S$. pileicola $(1.5-3.5 \mu \mathrm{m})$ with only 1-2 septa. In addition, this new taxon had obviously smaller conidia $(12.5-30 \times 0.6-2 \mu \mathrm{m})$ than $S$. chrysanthemella $(34-66 \times 2.5-3 \mu \mathrm{m})$ and $S$. longipes $(17-46.5 \times 1.5-2.5 \mu \mathrm{m})$ [35]. Septoria posoniensis and S. exotica have longer conidia, which was different to the new species $[33,34]$. DNA base differences indicated these three strains had nearly the identical sequence data (only two different bases on ITS region), but on protein-coding genes possessed more differences to distinguish them from related species (Supplementary Table S1). GCPSR test also provided a powerful proof to clarify them as different species.

(2) Septoria pileicola Y.Y. An \& Yong Wang bis sp. nov. (Figure 4)

MycoBank MB 839126

Etymology: The name refers to the plant host from which the fungus was collected.

Description in vitro: Colonies: on PDA up to 10-15 mm diameter, with an even, glabrous, colourless margin in 2 weeks. Mycelium: greenish grey to dark slate-blue, immersed, throughout covered by well-developed, tufty whitish-grey aerial mycelium that later attains a reddish haze; reverse black, but margin paler; in the central part of the colony numerous pycnidia develop, releasing pale vinaceous to rosy-buff conidial ball. Conidiomata: pycnidial, epiphyllous but sometimes also visible from the underside of the lesion, one to a few in each leaf spot, subglobose to globose, brown to black, usually fully immersed, 80-120 $\mu \mathrm{m}$ diam. Ostiolum: central, initially circular and 15-30 $\mu \mathrm{m}$ wide, later becoming more irregular and up to $45 \mu \mathrm{m}$ wide, surrounding cells concolorous to pale brown. Conidiogenous cells: hyaline, discrete, doliiform, or narrowly to broadly ampulliform, holoblastic, with a relatively narrow elongated neck, proliferating percurrently several times with distinct annellations, often also sympodially after a few percurrent proliferations, 5.5-12 × 2-3.5 $\mu \mathrm{m}$. Conidia: cylindrical or filiform-cylindrical, straight to slightly curved, narrowly to broadly rounded at the apex, narrowing slightly or more distinctly to a truncate base, (0-)1-2-septate, not or slightly constricted around the septa, hyaline, contents with a few minute oil-droplets and granular material in each cell in the rehydrated state, $8.5-30 \times 1.5-3.5 \mu \mathrm{m}$. Sexual morph unknown. 

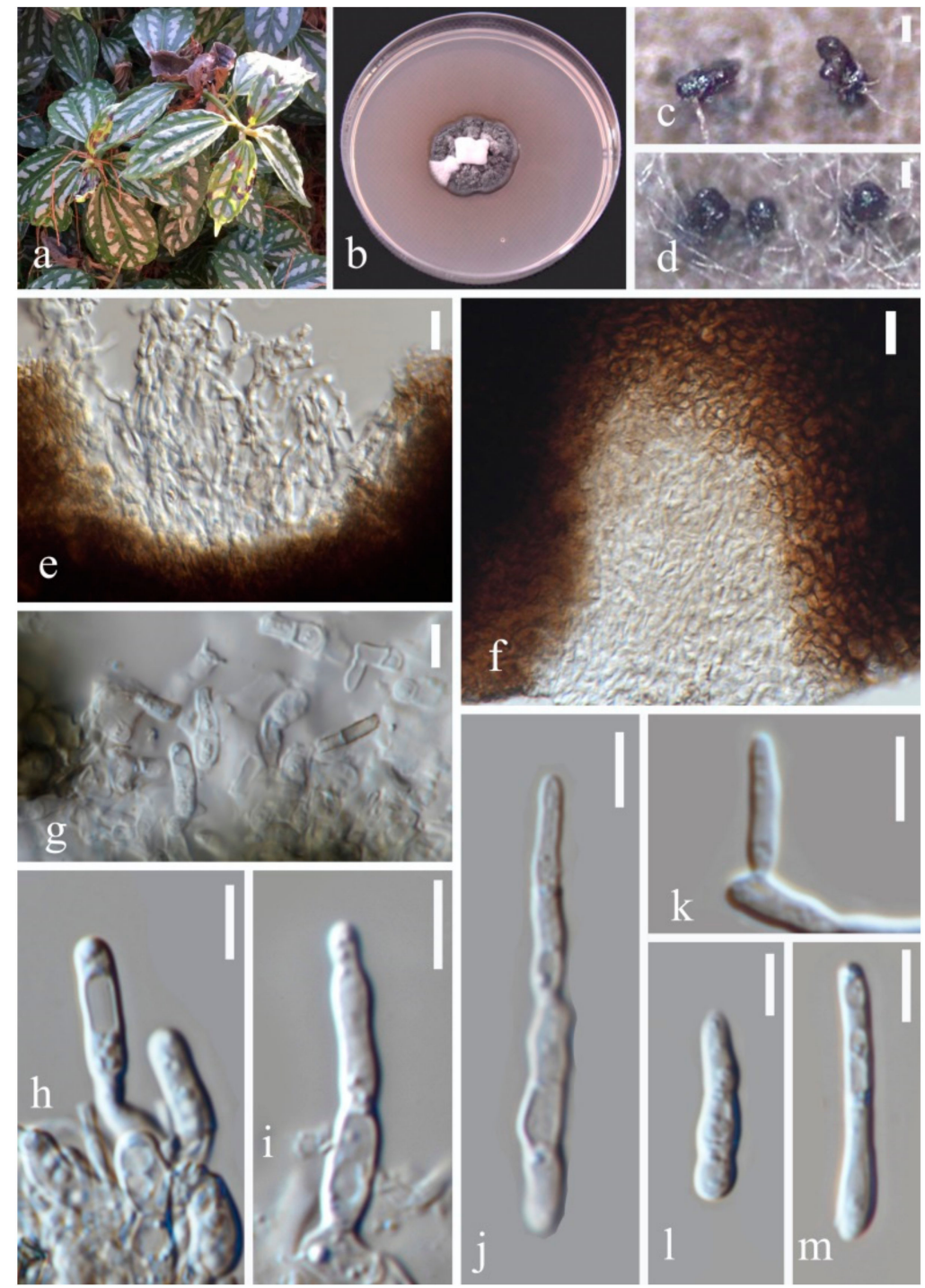

Figure 4. Septoria pileicola (GUCC 2131.4): (a) Leaf spot symptoms on the host. (b) Colonies on PDA culture. $(\mathbf{c}, \mathbf{d})$ Conidiomata on PDA culture. $(\mathbf{e}, \mathbf{f})$ Section though conidioma. $(\mathbf{g}-\mathbf{k})$ Conidiogenous cells. $(\mathbf{l}, \mathbf{m})$ conidia. Scale bars: $(\mathbf{c}, \mathbf{d})=125 \mu \mathrm{m},(\mathbf{e}-\mathbf{g})=10 \mu \mathrm{m},(\mathbf{h}-\mathbf{m})=10 \mu \mathrm{m}$.

Type: CHINA, Yunnan Province, Kunming Botanical Garden, from leaves of Pilea cadierei Gagnep. \& Guillaumin, February 2018, Y.Y. An (HGUP 2131.4, holotype); ex-type culture GUCC 2131.4; isotype culture MFLUCC 20-0184.

Other material examined: CHINA, Yunnan Province, Kunming Botanical Garden, from leaves of Pilea cadierei, February 2018, Y.Y. An (HGUP 2131.3).

Note: Phylogenetic analyses based on five gene regions showed that Septoria pileicola strains GUCC 2131.3 and GUCC 2131.4 are closely related to S. chrysanthemella, S. exotica, S. longipes, S. posoniensis, and S. sanguisorbigena (Figure 1), but formed a subclade with S. sanguisorbigena. After morphological comparisons, we found that Septoria pileicola can be distinguished from $S$. sanguisorbigena by its wider conidia, and from S. posoniensis and S. exotica by its shorter conidia with obviously fewer septa [36,37]. For S. chrysanthemella and S. longipes, the species had apparently shorter conidia [35]. The two strains of Septoria pileicola had nearly the identical sequences (only one different ITS base pair); however, the $t u b 2$ gene provided enough base distinction to separate it from related species (Supplementary Table S1) according to the guidelines of Jeewon and Hyde [38]. The PHI value was $0.116(>0.05)$, indicating no significant genetic recombination among S. pileicola, 
S. sanguisorbigena, S. chrysanthemella, S. exotica, and S. posoniensis. Thus, they should belong to different species [39].

(3) Septoria longipes Y.Y. An \& Yong Wang bis sp. nov. (Figure 5)

MycoBank MB 839127

Etymology: The name refers to the long conidia of this species.

Description in vitro: Colonies: on PDA 11-15 mm diameter, with an even, light brown to dark-brown margin in 2 weeks; immersed mycelium grey to dark slate-blue in the center, black near the margin. Aerial mycelium: well-developed, white to snow white, covering the colony surface. Conidiomata: pycnidial, numerous, mostly epiphyllous, semi-immersed, black, mostly $80-200 \mu \mathrm{m}$ diameter, with a central, first narrow, later wider opening, releasing pale white cirrhi of conidia. Conidiomatal wall: one or two layers of brown-walled, angular cells, lined by a layer of hyaline cells. Conidiogenous cells: hyaline, discrete, holoblastic, sympodially or percurrently proliferating, ampulliform, 8-16 $\times 1.5-5.5 \mu \mathrm{m}$. Conidia: filiform to filiform-cylindrical, straight, flexuous or curved, attenuated gradually to the narrowly rounded to pointed apex, attenuated gradually or more abruptly to the narrowly truncate base, $(0-) 3-5(-8)$-septate, $17-46.5 \times 1.5-2.5 \mu \mathrm{m}$. Sexual morph unknown.
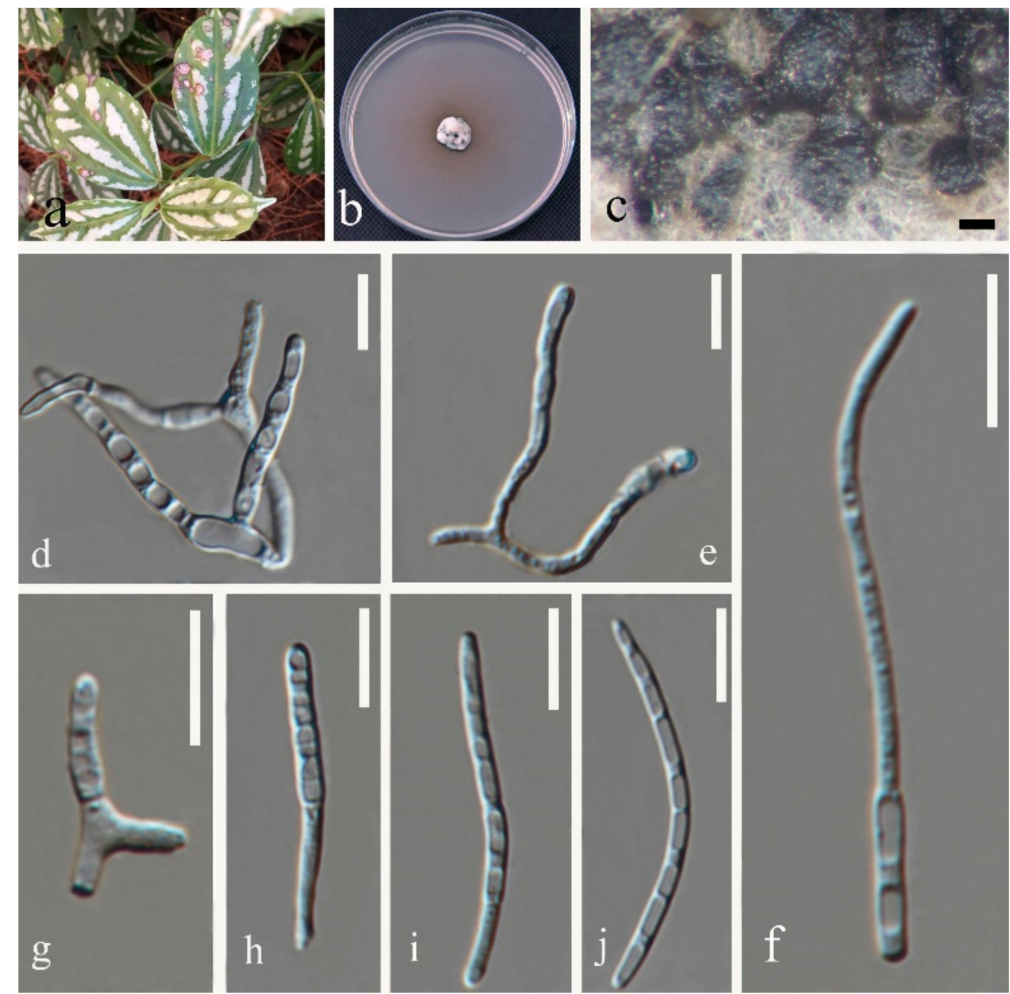

Figure 5. Septoria longipes (GUCC 2131.1) (a) Leaf spot symptoms on the host. (b) Colony on PDA. (c) Conidiomata on PDA culture. $(\mathbf{d}-\mathbf{g})$ Conidiophores, Conidiogenous cells and conidia. $(\mathbf{h}-\mathbf{j})$ Conidia. Scale bars: $(\mathbf{c})=20 \mu \mathrm{m} .(\mathbf{d}-\mathbf{j})=10 \mu \mathrm{m}$.

Type: CHINA, Yunnan Province, Kunming Botanical Garden, from leaves of Pilea cadierei Gagnep. \& Guillaumin, February 2018, Y.Y. An (HGUP 2131.1, holotype); ex-type culture GUCC 2131.1)

Notes: Only one strain (GUCC 2131.1) of this taxon was available. It clustered with S. posoniensis supported by MP (70\%) and Bayesian (0.93) analyses and is closely related to S. chrysanthemella, S. exotica, S. pileicola, and S. sanguisorbigena. Morphological comparisons indicated that GUCC 2131.1 differed from S. posoniensis by conidia by more septa, and from $S$. chrysanthemella $(4-10 \times 5-6 \mu \mathrm{m})$ by larger conidiogenous cells $(8-16 \times 1.5-5.5 \mu \mathrm{m})[35,36]$. This species produced longer conidia than S. pileicola and 
S. sanguisorbigena. It was confirmed that two protein-coding genes, except for tef1, provided enough base distinction with related species (Supplementary Table S1). GCPSR test also supported them as different species.

(4) Septoria dispori Y.Y. An \& Yong Wang bis sp. nov. (Figure 6)

MycoBank MB 839128

Etymology: The name refers to the plant host from which the fungus was collected.

Description in vitro: Colonies: on PDA 2.0-3.5 mm diameter, with an even to slightly ruffled, glabrous, dull yellow margin in 2 weeks, spreading, remaining almost plane, immersed mycelium yellowish brown to brown; aerial mycelium well-developed, goose feather flocculent on the surface of the colony; numerous conidiomatal initials developing at the surface, mature ones releasing cirrhi of conidia that first are milky white, later salmon, sometimes merging to form slimy masses covering areas of the colony surface. Conidiogenous cells: hyaline, broadly or elongated ampulliform, normally with a distinct neck, hyaline, holoblastic, proliferating percurrently, annellations indistinct, 10-15 $\times 1.5-2.5 \mu \mathrm{m}$. Conidia: cylindrical to filiform-cylindrical, slightly to strongly curved, rarely somewhat flexuous, narrowly rounded to pointed at the apex, attenuated gradually or more abruptly towards a narrowly truncate base, 3-5-8-septate, later with secondary septa dividing the cells, sometimes breaking up into smaller fragments in the cirrhus, not or slightly constricted around the septa, hyaline, 14-41.5 × 1.5-2.5 $\mu \mathrm{m}$. Sexual morph unknown.

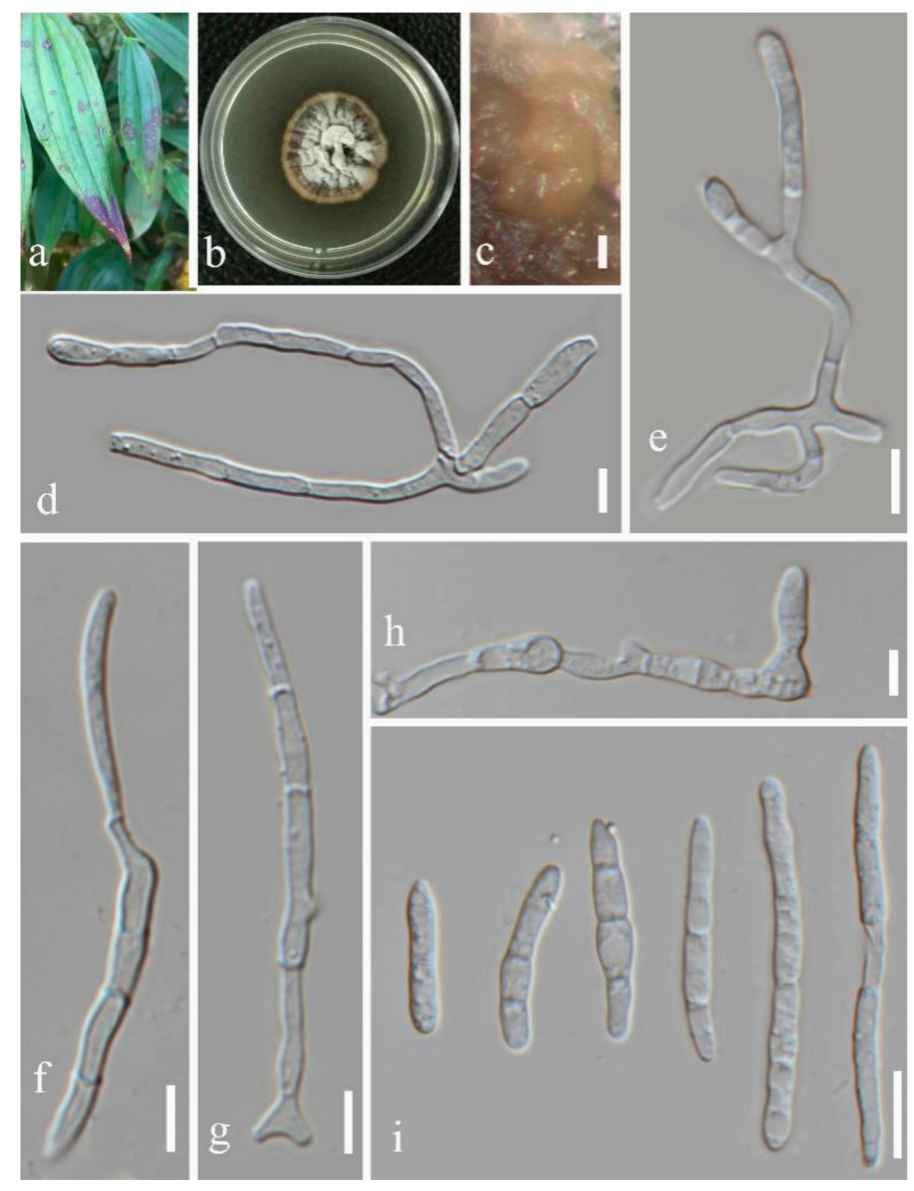

Figure 6. Septoria dispori (GUCC 2127.1) (a) Leaf spot symptoms on the host. (b) Colony on PDA. (c) Conidiomata on PDA culture. (d,e) Conidiophores. (f-h) Conidiogenous cells and conidia. (i) Conidia. Scale bars: $(\mathbf{c})=20 \mu \mathrm{m},(\mathbf{d})=10 \mu \mathrm{m}(\mathbf{e})=5 \mu \mathrm{m},(\mathbf{f}-\mathbf{i})=10 \mu \mathrm{m}$.

Type: CHINA, Yunnan Province, Botanical Garden of Kunming country, from leaves of Disporum bodinieri (Levl. et Vaniot.) Wang et Y. C. Tang, February 2018, Y.Y. An (HGUP 2127.1, holotype); ex-type culture GUCC 2127.1. 
Other material examined: CHINA, Yunnan Province, Kunming Botanical Garden, from leaves of Disporum bodinieri, February 2018, Y.Y. An (HGUP 2127.4); from leaves of Sanguisorba officinalis L., February 2018, Y.Y. An (HGUP 2164.3 and HGUP 2164.4).

Note: Four strains (GUCC 2127.1, GUCC 2127.4, GUCC 2164.3, and GUCC 2164.4) of Septoria dispori clustered together with high statistical support (MP: 95\%, ML: 100\%, BPP: 1.00) adjacent to $S$. coprosmae and S. verbenae. Thus, we consider these four strains to be a single species. Septoria coprosmae produced spermatogonia of an Asteromella-state, but this species did not [40]. Conidia of $S$. verbenae possessed fewer septa than those of Septoria dispori [41]. GUCC 2127.4 showed some phylogenetic distance from the other three strains, however DNA base comparison (Supplementary Table S1) revealed only 11 bases that had tub2 differences. The PHT test confirmed significant recombination between strains GUCC 2164. 4 and GUCC 2164.3 and they were morphologically similar. Thus by combining the above evidence, we established the four strains as a new taxon.

(5) Septoria protearum Viljoen \& Crous, in Swart, Crous, Denman \& Palm, S. Afr. J. Bot. 64(2): 144 (1998) (Figure 7)

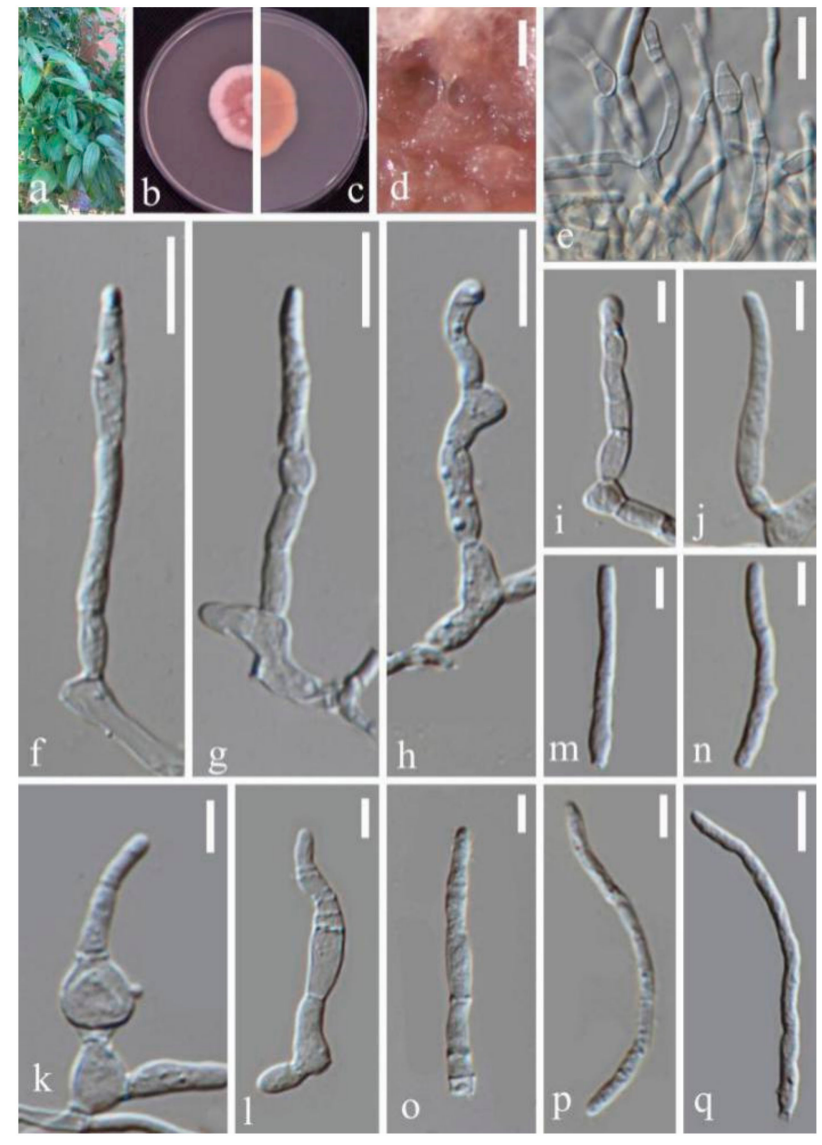

Figure 7. Septoria protearum (GUCC 2127.3) (a. Leaf spot symptoms on the host. (b,c) Colony on PDA. (b) From above; c. from below). (d) Mycelium. (e) Conidiophores. (f-l) Conidiogenous cells and conidia. $(\mathbf{m}-\mathbf{q})$ Conidia. Scale bars: $(\mathbf{d})=125 \mu \mathrm{m} .(\mathbf{e}-\mathbf{h})=10 \mu \mathrm{m} .(\mathbf{i})=5 \mu \mathrm{m} .(\mathbf{j}-\mathbf{q})=10 \mu \mathrm{m}$.

Description in vitro: Colonies: on PDA $15-25 \mathrm{~mm}$ with an even, glabrous white margin in 2 weeks, plane spreading, immersed. Mycelium: pink, lacking aerial hypha. Conidiomata developing after 1 week, mostly immersed and releasing whitish conidial slime. Conidiogenous cells: hyaline, cylindrical, broadly to narrowly ampulliform, with a distinct neck of variable length, holoblastic, with several distinct percurrent proliferations, more rarely also sympodial after a sequence of percurrent proliferations of the same cell, $5-10(-13.5) \times 2.5-3(-3.5) \mu \mathrm{m}$. Conidia: filiform, straight, more often irregularly 
curved, 0-4 septate, not or only inconspicuously constricted around the septa, hyaline, 16-25 × 2.5-3.5 $\mu \mathrm{m}$. Sexual morph unknown.

Material examined: CHINA, Yunnan Province, Kunming Botanical Garden, from leaves of Disporum bodinieri (Levl. et Vaniot.) Wang et Y. C. Tang, February 2018, Y.Y. An (HGUP 2127.3), living culture GUCC 2127.3.

Notes: DNA base comparison (Supplementary Table S1), revealed that sequences of strain GUCC 2127.3 were identical to the ex-type strain of S. protearum (CBS 778.97) in four gene regions. Conidial shape and size range of $S$. protearum $(12-22 \times 1.5-2 \mu \mathrm{m})$ were similar to the present strain [42]. The number of conidial septa of the two strains was also the same (0-4 septa). Thus, we conclude that GUCC 2127.3 is S. protearum.

\section{Discussion}

Verkley et al. [3] pointed out that for the identification of the Septoria species, morphological description must be integrated with sequences analyses. Quaedvlieg et al. [10] treated species in Septoria within a modern taxonomic framework and pointed out that Septoria spp. formed a well-defined phylogenetic clade. Regarding morphology, the species concept was to produce pycnidial, ostiolate conidiomata; conidiophores reduced to conidiogenous cells that proliferate sympodially; and hyaline, filiform conidia with transverse eusepta that fit the original concept of [4]. We followed this system and applied morphological and phylogenetic approaches to the present study. After comparing the topologies of five single-gene and two multi-gene trees (Figures 1 and 2 and Supplementary Figures S1-S5), we showed that Septoria forms two branches (Branch 1 and Branch 2), mainly because only the phylogenetic trees based on the LSU region and five DNA fragments (including LSU) supported three branches, whereas the conserved LSU sequences included the least parsimonious characters (31/799) (Table 3). In morphology, all species in Branch 3 produced filiform or fusiform, sub-straight to slightly curved conidia mainly with 3 septa, which was not a unique characteristic. Thus, we proposed exclusion of the LSU region for multi-gene analyses of Septoria at the species level, but always as the primary DNA barcode with more parsimonious characters (43/486), the ITS fragment was conserved in the present phylogenetic analysis.

The S. protearum complex accommodated eight members: S. citri, S. citicola, S. chamaecisti, S. gerberae, S. hederae, S. lobelia, S. limonum, and S. protearum, according to Verkley et al. [3]. Apart from $S$. protearum, the other species were old names without ex-type cultures, and thus no sequences were available. The base comparison of DNA sequences originated from Verkley et al. [3], who indicated that among these eight species there were only approximately 10 base-pair differences on the $r p b 2$ fragment (434 characters) of $S$. gerberae, $S$. hederae, and S. lobelia compared to the other five species, while for the other four gene regions, their sequences were nearly identical ( $\leq 1$ base difference) (Supplementary Table S1). On the other hand, in the literature these seven species are depicted only by simple descriptions often without drawings or photographs, which does not strongly support them as different taxa. Comparing with the sequences from Verkley et al. [3] and in the absence of type materials, we were more willing to believe that they belonged to the same species, S. protearum.

Our 11 strains isolated from Disporum bodinieri, Pilea cadierei, Sanguisorba officinalis all from the Botanical Garden of Kunming county represented five Septoria species and included four novel species supported by morphology and phylogeny. Septoria sanguisorbigena was obtained from two plant hosts (Sanguisorba officinalis and P. cadierei), and S. dispori was also on two hosts (D. bodinieri and Sanguisorba officinalis). Septoria pileicola and S. longipes were only discovered on one host (P. cadierei). Our S. protearum strain was on $D$. bodinieri. Verkley et al. [3] recalled that trans-family host jumping must be a major force driving the evolution of Septoria. Our results support this hypothesis as we found the same species on different hosts. However, our findings revealed that the Septoria species did not show any host specialization, which differs from the view of Verkley et al. [3]. 


\section{Conclusions}

In this study, our 11 Septoria strains represented five species including four novel taxa, and one new record for China by morphological comparison and multi-gene analyses. The Septoria species are pathogens often causing leaf spot diseases of many plant hosts worldwide [10]. Based on previous studies, relatively sufficient reference sequences are available for rapid identification of Septoria pathogens. By comparing the parsimoniousinformative characters of different DNA fragments (Supplementary Table S1), we showed that either tef1 or $t u b 2$ is suitable as a secondary DNA barcode, and that the latter was more discriminating than the former. Moreover, the DNA fragment of $t u b 2(\approx 300 \mathrm{bp})$ was shorter than that of tef1 $(\approx 450 \mathrm{bp})$ with a high PCR amplification success rate. Consequently, a standardized approach including morphological characters and phylogenetic analysis is needed for the correct and precise identification of Septoria isolates.

Supplementary Materials: The following are available online at https: / www.mdpi.com/article/ 10.3390/jof7060483/s1. Figure S1: The phylogenetic tree based on ITS region. Figure S2: The phylogenetic tree based on LSU region. Figure S3: The phylogenetic tree based on $r p b 2$ region. Figure S4: The phylogenetic tree based on tef1 region. Figure S5: The phylogenetic tree based on tub2 region. Cercospora beticola (CBS 124.31) was used as outgroup taxon. MP and ML above $50 \%$ and BPP above 0.90 were placed close to topological nodes and separated by "/", otherwise were labeled with "-". Taxa from this study are highlighted in green. Table S1: DNA base difference between our Septoria strains and related species.

Author Contributions: Morphological and phylogenetic analyses, Y.-Y.A.; GCPSR analyses, M.C.D.; data curation, X.-Y.Z.; writing—original draft preparation, Y.W.; writing—-review and editing, K.D.H. and A.J.L.P. All authors have read and agreed to the published version of the manuscript.

Funding: The study was funded by the National Natural Science Foundation of China (No. 31972222, 31560489), Program of Introducing Talents of Discipline to Universities of China (111 Program, D20023), Talent project of Guizhou Science and Technology Cooperation Platform ((2017)5788-5 and (2019)5641), Guizhou Science, Technology Department of International Cooperation Base project ((2018)5806), Guizhou Science and Technology Innovation Talent Team Project ((2020)5001), and UIDB/04046/2020 and UIDP/04046/2020 Centre grants from FCT, Portugal (to BioISI).

Institutional Review Board Statement: Not applicable.

Informed Consent Statement: Not applicable.

Data Availability Statement: The data presented in this study are available in Supplementary Figures S1-S5 and Table S1.

Acknowledgments: The authors would like to thank anonymous reviewers for helpful comments.

Conflicts of Interest: The authors declare no conflict of interest.

\section{References}

1. Index Fungorum 2020. Available online: http://www.indexfungorum.org/names/Names.asp (accessed on 8 October 2020).

2. Wijayawardene, N.N.; Hyde, K.D.; Al-Ani, L.K.T.; Tedersoo, L.; Haelewaters, D.; Rajeshkumar, K.C.; Zhao, R.L.; Aptroot, A.; Leontyev, D.V.; Saxena, R.K.; et al. Outline of Fungi and fungus-like taxa. Mycosphere 2020, 11, 1060-1456. [CrossRef]

3. Verkley, G.J.M.; Quaedvlieg, W.; Shin, H.D.; Crous, P.W. A new approach to species delimitation in Septoria. Stud. Mycol. 2013, 75, 213-305. [CrossRef]

4. Sutton, B.C. The Coelomycetes. Fungi Imperfecti with Pycnidia, Acervuli and Stromata; Commonwealth Mycological Institute: Kew, UK, 1980.

5. Constantinescu, O. Taxonomic revision of Septoria-like fungi parasitic on Betulaceae. Trans. Br. Mycol. Soc. 1984, 83, 383-398. [CrossRef]

6. Sutton, B.C.; Pascoe, I.G. Septoria species on Acacia. Trans. Br. Mycol. Soc. 1987, 89, 521-532. [CrossRef]

7. Sutton, B.C.; Pascoe, I.G. Some Septoria species on native Australian plants. Stud. Mycol. 1989, 31, 177-186.

8. Farr, D.F. Septoria species on Cornus. Mycologia 1991, 83, 611-623. [CrossRef]

9. Farr, D.F. Species of Septoria on the Fabaceae, subfamily Faboidae, tribe Genistae. Sydowia 1992, 44, $13-31$.

10. Quaedvlieg, W.; Verkley, G.J.M.; Shin, H.D.; Barretto, R.W.; Alfenas, A.C.; Swart, W.J.; Groenewald, J.Z.; Crous, P.W. Sizing up Septoria. Stud. Mycol. 2013, 75, 307-390. [CrossRef] 
11. Crous, P.W.; Shivas, R.G.; Quaedvlieg, W.; van der Bank, M.; Zhang, Y.; Summerell, B.A.; Guarro, J.; Wingfield, M.J.; Wood, A.R.; Alfenas, A.C.; et al. Fungal Planet Description Sheets: 214-280. Persoonia 2014, 32, 184-306. [CrossRef]

12. Crous, P.W.; Schumacher, R.K.; Wingfield, M.J.; Lombard, L.; Giraldo, A.; Christensen, M.; Gardiennet, A.; Nakashima, C.; Pereira, O.; Smith, A.J.; et al. Fungal Systematics and Evolution: FUSE 1. Sydowia 2015, 67, 81-118.

13. Senanayake, I.C.; Rathnayaka, A.R.; Marasinghe, D.S.; Calabon, M.; Vedprakash, H.G. Morphological approaches in studying fungi: Collection, examination, isolation, sporulation and preservation. Mycosphere 2020, 11, 2678-2754. [CrossRef]

14. Braun, U.; Nakashima, C.; Bakhshi, M.; Zare, R.; Shin, H.D.; Alves, R.F.; Sposito, M.B. Taxonomy and phylogeny of cercosporoid ascomycetes on Diospyros spp. with special emphasis on Pseudocercospora spp. Fungal Syst. Evol. 2020, 6, 95-127. [CrossRef]

15. Dissanayake, A.J.; Bhunjun, C.S.; Maharachchikumbura, S.S.N.; Liu, J.K. Applied aspects of methods to infer phylogenetic relationships amongst fungi. Mycosphere 2020, 11, 2652-2676. [CrossRef]

16. Kuraku, S.; Zmasek, C.M.; Nishimura, O.; Katoh, K. Leaves facilitates on-demand exploration of metazoan gene family trees on MAFFT sequence alignment server with enhanced interactivity. Nucleic Acids Res. 2013, 41, W22-W28. [CrossRef] [PubMed]

17. Katoh, K.; Rozewicki, J.; Yamada, K.D. MAFFT online service: Multiple sequence alignment, interactive sequence choice and visualization. Brief. Bioinform. 2017, 20, 1160-1166. [CrossRef]

18. Carbone, I.; Kohn, L.M. A method for designing primer sets for speciation studies in fifilamentous ascomycetes. Mycologia 1999, 91, 553-556. [CrossRef]

19. O'Donnell, K.; Kistler, H.C.; Cigelnik, E.; Ploetz, R.C. Multiple evolutionary origins of the fungus causing Panama disease of banana: Concordant evidence from nuclear and mitochondrial gene genealogies. Proc. Natl. Acad. Sci. USA 1998, 95, 2044-2049. [CrossRef]

20. O'Donnell, K.; Cigelnik, E. Two divergent intragenomic rDNA ITS2 types within a monophyletic lineage of the fungus Fusarium are nonorthologous. Mol. Phylogenetics Evol. 1997, 7, 103-116. [CrossRef] [PubMed]

21. Stukenbrock, E.H.; Quaedvlieg, W.; Javan-Nikhah, M.; Zala, M.; Crous, P.W.; McDonald, B.A. Zymoseptoria ardabilia and Z. pseudotritici, two progenitor species of the Septoria tritici leaf blotch fungus Z. tritici (synonym: Mycosphaerella graminicola). Mycologia 2012, 104, 1397-1407. [CrossRef]

22. Liu, Y.; Whelen, S.; Hall, B. Phylogenetic relationships among ascomycetes: Evidence from an RNA polymerse II subunit. Mol. Biol. Evol. 1999, 16, 1799-1808. [CrossRef]

23. Quaedvlieg, W.; Kema, G.H.J.; Groenewald, J.Z.; Verkley, G.J.M.; Seifbarghi, S.; Razavi, M.; Gohari, A.M.; Mehrabi, R.; Crous, P.W. Zymoseptoria gen. nov.: A new genus to accommodate Septoria-like species occurring on graminicolous hosts. Persoonia 2011, 26, 57-69. [CrossRef] [PubMed]

24. Crous, P.W.; Braun, U.; Wingfield, M.J.; Wood, A.R.; Shin, H.D.; Summerell, B.A.; Alfenas, A.C.; Cumagun, C.J.; Groenewald, J.Z. Phylogeny and taxonomy of obscure genera of microfungi. Persoonia 2009, 22, 139-161. [CrossRef]

25. Vilgalys, R.; Hester, M. Rapid genetic identifification and mapping of enzymatically amplifified ribosomal DNA from several Cryptococcus species. J. Bacteriol. 1990, 172, 4238-4246. [CrossRef] [PubMed]

26. White, T.J.; Bruns, T.; Lee, S.; Taylor, J.W. Amplifification and direct sequencing of fungal ribosomal RNA genes for phylogenetics. In PCR Protocols: A Guide to Methods and Applications; Innis, M.A., Gelfland, D.H., Sininsky, J.J., White, T.J., Eds.; Academic Press: San Diego, CA, USA, 1990; pp. 315-322.

27. Tamura, K.; Peterson, D.; Peterson, N.; Stecher, G.; Nei, M.; Kumar, S. MEGA5: Molecular evolutionary genetics analysis using maximum likelihood, evolutionary distance, and maximum parsimony methods. Mol. Biol. Evol. 2011, 28, 2731-2739. [CrossRef] [PubMed]

28. Swofford, D.L. PAUP_Phylogenetic Analysis Using Parsimony and Other Methods; Version 4; Sinauer Associates: Sunderland, MA, USA, 2003.

29. Hillis, D.M.; Bull, J.J. An empirical test of bootstrapping as a method for assessing confidence in phylogenetic analysis. Syst. Biol. 1993, 42, 182-192. [CrossRef]

30. CIPRES Science Gateway. Available online: https://www.phylo.org/portal2/login.action (accessed on 22 June 2020).

31. FigTree. Available online: http://tree.bio.ed.ac.uk/software/figtree (accessed on 22 June 2020).

32. Quaedvlieg, W.; Binder, M.; Groenewald, J.Z.; Summerell, B.A.; Carnegie, A.J.; Burgess, T.I.; Crous, P.W. Introducing the consolidated species concept to resolve species in the Teratosphaeriaceae. Persoonia 2014, 33, 1-40. [CrossRef] [PubMed]

33. Huson, M.G. Physical properties of wool fibers in electrolyte solutions. Text. Res. J. 1998, 68, 595-605. [CrossRef]

34. Huson, D.H.; Bryant, D. Application of phylogenetic networks in evolutionary studies. Mol. Biol. Evol. 2006, $23,254-267$. [CrossRef]

35. Saccardo, P.A. Supplementum Universale, Pars. III. Sylloge Fungorum 1895, 11, 1-753.

36. Bäumler, J.A. Mycologisches aus Pressburg. Hedwigia 1885, 24, 75.

37. Spegazzini, C. Fungi argentini. Pugillus secundus (Continuacion). An. Soc. Cient. Argent. 1880, 10, 5-33.

38. Jeewon, R.; Hyde, K.D. Establishing species boundaries and new taxa among fungi: Recommendations to resolve taxonomic ambiguities. Mycosphere 2016, 7, 1669-1677. [CrossRef]

39. Chethana, K.W.T.; Zhou, Y.; Zhang, W.; Liu, M.; Xing, Q.K.; Hyde, K.D.; Yan, J.Y.; Li, X.H. Coniella vitis sp. nov. is the common pathogen of white rot in Chinese vineyards. Plant Dis. 2017, 101, 2123-2136. [CrossRef]

40. Cooke, M.C. Some exotic fungi. Grevillea 1886, 14, 129-130. 
41. Saccardo, P.A. Sylloge Fungorum: Sylloge Sphaeropsidearum et Melanconiearum; Sumptibus auctoris: Patavii, Italy, 1884; Volume 3, pp. 1-860.

42. Swart, L.; Crous, P.W.; Denman, S.; Palm, M.E. Fungi occurring on Proteaceae. I. S. Afr. J. Bot. 1998, 64, 137-146. [CrossRef] 